\title{
EFFECT OF PLASTIC TUNNEL SIZE ON PRODUCTION OF CUCUMBER IN DELTA OF EGYPT
}

\author{
F. EL-AIDY - A. EL-ZAWELY - N. HASSAN - M. EL-SAWY \\ Dept. of Hort., Fac. of Agriculture, Tanta University \\ 33516 Kafr El-Sheikh, Egypt \\ e-mail:faelaidy@yahoo.com.au
}

(Received $4^{\text {th }}$ April 2006; accepted $13^{\text {th }}$ June 2007)

\begin{abstract}
The experiments were carried out in the years of 2000, 2001 and 2003 at Kafr El-Sheikh. The main objective of this research was to study the influence of growing seasons and types of unheated plastic house on yields of two cucumber $F_{1}$ hybrids. Downy mildew and powdery mildew were lower in the winter season than during the early summer season. Likewise, they were lower inside the double span house than inside the single span house (at 60 days after transplanting). The highest total yield as number and weight was produced from Petostar hybrid grown inside the double span house during the early summer season.
\end{abstract}

Keywords: plastic tunnels, cucumber, seasons, cultivars

\section{Introduction}

In the recent years, growing vegetables under protected cultivation in Egypt is expanding rapidly. The common types of protected cultivation in Egypt are the plastic low tunnels and the single span plastic houses. The number of single-arch greenhouses reached about twenty thousand, when about $12000(60 \%)$ are used for cucumber production.

For obtaining higher energy efficiency and economic use of construction materials, several changes in the type of houses have been recommended. Most of the modifications in greenhouse construction were related to the construction of the multiple span houses instead of the single span. Multiple span houses with higher roofs are believed to be more suitable for the continental climate than the single houses.

Therefore, the present study aimed to evaluate two new cucumber $F_{1}$ hybrid cvs. (Primo and Petostar) under single span and double span plastic houses during the winter and early summer seasons, under Kafr El-Sheikh conditions.

Welles et al. (1999) [35] studied the influence of cultural factors on fruit quality of glasshouse cucumber. They found that cultivar choice had the largest impact. Air temperature, humidity, plant density and leaf area index had negative effects, but light intensity, fertilizers and certain growing media had positive effects on quality. Combining these factors improves fruit quality substantially, but isn't enough for giving quality guaranties to buyers. However, recent research data on a new growing system, the high wire system (HWS), plants did not top but allowed to grow up to $3.5 \mathrm{~m}$ high, showing that high yields of excellent fruit quality (keeping quality) can be obtained almost all year-round.

Papadopoulos et al. (2000) [31] studied the effects of day and night air temperature (DT and NT) on growth of long English cucumber in the spring season. They indicated that plant development rates (leaves number) were linearly increased with increasing daily average air temperature (MT), but weren't affected by day-night air temperature 
difference (DIF). Also, plant development rates increased with increasing air temperature regardless of DT or NT.

High temperature in summer under plastic house could cause plant injury to cucumber and tomato in Egypt [15].

The main effect for humidity is on leaf expansion which is favoured by high humidity (through improving water balance), but may be counteracted by a negative effect, in some crops caused by calcium deficiency in the leaves through a reduction of transpiration [2], [26]. Also, [2] found that the positive effect of air humidity on stomatal conductance results in only a minor effect on crop photosynthesis.

Regional climate differences have a major effect on ventilation choice. Natural ventilation is most common (61\%), followed by fans (17\%) and pads (11\%).Gas-fired heaters are most common (61\%) followed by hot water perimeter pipers (28\%), [3].

The main problems are the high costs of materials required for protected cultivation, unsuitable ventilation of the existing tunnels and the unacceptable (to local consumers) intensive use of pesticides [18].

The results of long term work by El-Aidy (1979) [14] and Abou-Khaled and El-Aidy (1986) [1] introduced eleven types of plastic tunnels (types of I, II, III and IV) and greenhouses (types, V, VI, VII, VIII, IX and Nobaria) varying from low tunnels type to large volume type which cover $1200 \mathrm{~m}^{2}$, in two generations of development. The second generation offers a simple solution to achieve sufficient ventilation in attempt to solve most of the first generation problems. Also, they reported that in spite of all presented types of the plastic tunnels or greenhouses correspond to a medium advanced stage.

Farag (2001) [21] studied the effect of natural ventilation (as side and top ventilation) on growth and yield of cucumber plant cv. Primo $F_{1}$ hybrid in unheated single plastic houses. He showed that using the side ventilation during the summer season reduced maximum and minimum relative humidity, and air temperatures as well as average soil temperature compared with top ventilation and control. Likewise, it surpassed vegetative growth and fruit yields, compared with top ventilation and control which had the lowest values.

Castilla and Lopez-Galvez (1994) [6] evaluated two new unheated prototype greenhouse (a north-south oriented multispan of symmetrical 17 roof slope and an eastwest oriented singlespan of asymmetrical roof angles, 18 and 8, as possible alternatives to the conventional flat-roofed greenhouse. They found that around the winter solstice, the higher light transmission in the asymmetrical singlespan houses significantly increased cucumber yields, relative to those grown in a conventional plastic house. Also, the multispan structure generated lower radiation transmissivity in spring.

Chen et al. (1989) [8] indicated that increasing natural ventilation (in plastic greenhouse) by $3 \mathrm{~h}$ in the morning and at night every day from the end of April to the first 10 days of May, reduced the dew duration on cucumber leaves. The use of natural ventilation for the whole night within the second 10 days and the last 10 days of May reduced downy mildew by $86 \%$ and $46 \%$, respectively.

Ten cucumber cultivars were compared for their yield, quality and resistance to diseases when cultivated in unheated greenhouse by Leber and Heck (1991) [29]. They showed that the highest yields were obtained with cv. Birgit $\left(40.3\right.$ fruits $/ \mathrm{m}^{2}$ or 26.1 $\mathrm{kg} / \mathrm{m}^{2}$ ). Also, the same variety was more resistant to powdery mildew (Erysiphe cichoracearum). 
The influence of the planting date during the winter and summer seasons was studied by El-Aidy (1989 and 1990) [16], [17]. He showed that the best vegetative growth was obtained from the plants cultivated in October, while the worst one was obtained from November planting dates. The yield was decreased as the transplanting date delayed. The decreasing yield at late transplanting dates might be due to the highly increase in air temperature a result of the plastic covers. Also, the effect of production season on the average yield of some cucumber varieties and their interaction was studied. The differences were significant. All of the varieties used in the present study produced more yield during the early summer season. The differences were between $23 \%$ and $81 \%$

\section{Materials and methods}

The study was conducted during four successive growing seasons starting from 2000 to 2002 at Sakha (Kafr El-Sheikh Governorate) Protected Cultivation Site, Ministry of Agriculture.

Treatments used: The experiment included three factors as follows:

A. Growing seasons: Two seasons were tested, the first was the winter season and the second was the early summer season. Dates of sowing in plastic seedling trays were 27 September in the winter season and 10 January in the early summer season in both years. Likewise, the dates of transplanting of cucumber under plastic houses were 10 October in the winter season and 2 February in the early summer season in both years.

B Type (size) of unheated plastic houses: Single span plastic house with top ventilation having round-arch (3.2 m height, $8.5 \mathrm{~m}$ width and $55 \mathrm{~m}$ length) which was covered an area of $467.5 \mathrm{~m}^{2}$ as showing in (Fig. 1). It was divided into five ridges. Each ridge was $150 \mathrm{~cm}$ width.

Double span plastic house with side ventilation having round-arch (5.1 m height, 17 $\mathrm{m}$ width and $55 \mathrm{~m}$ length which was covered an area of $935 \mathrm{~m}^{2}$ ) as showing in (Fig. 2). It was divided into ten ridges.

Both plastic house types were covered with UV polyethylene film with thickness of 200 microns.

\section{C.Cucumber treatments:}

Two hybrids of cucumber cvs Petostar and Primo were used.

\section{Nursery material and cultural practices}

In winter and early summer season, seeds of cucumber cvs Petostar and Primo $\mathrm{F}_{1}$ hybrids were sown in seedling trays The seedlings were transplanted into an unheated plastic houses when they reached the second true leaf stage (13 days age) on 10 Oct. and 2 Feb. in both years.

Transplanting took place on both sides of each ridge at space of $45 \mathrm{~cm}$ (planting density was 3 plants $/ \mathrm{m}^{2}$ ).

Cucumber plants were trained vertically on single stem. All cultural practices (cultivation, nutrition, pests and diseases control and others) were carried out whenever they were necessary.

APPLIED ECOLOGY AND ENVIRONMENTAL RESEARCH 5(2): 11-24.

http://www.ecology.uni-corvinus.hu $\bullet$ ISSN 15891623

(C) 2007, Penkala Bt., Budapest, Hungary 
Harvesting started on Nov. $10^{\text {th }}$ (after 31 days from transplanting date) and continued for 67 days until 15 Jan. in the winter season and on Mar. $18^{\text {th }}$ (after 44 days from transplanting date) and continued for 82 days until June $7^{\text {th }}$ in the early summer season in both years of 2001 and 2002. Number of pickings in winter and early summer seasons were 32 and 42 , respectively.
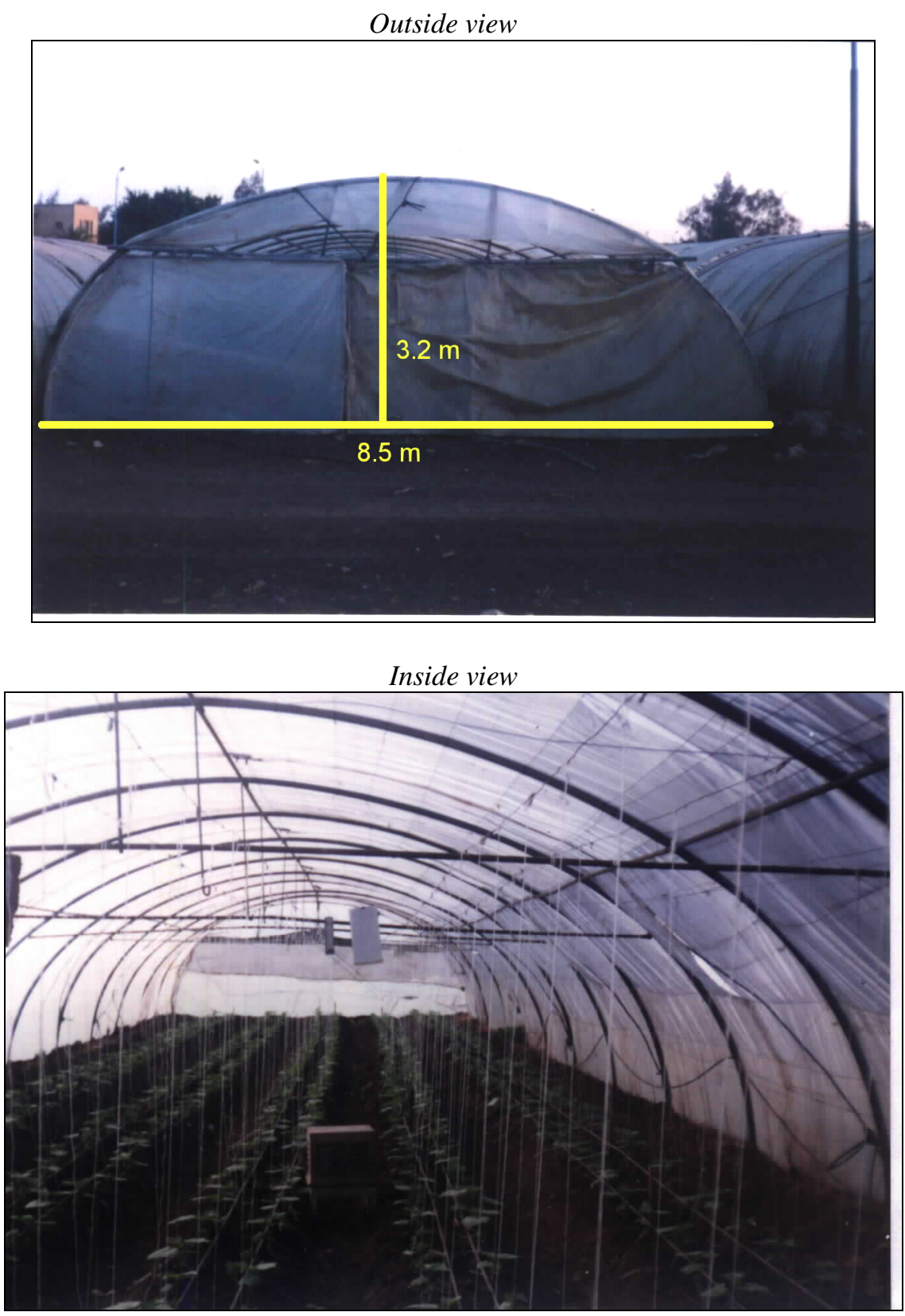

Figure 1. Singlespan plastic house having one round-arch (3.2 $\mathrm{m}$ height, $8.5 \mathrm{~m}$ width and $55 \mathrm{~m}$ length) covered an area of $467.5 \mathrm{~m}^{2}$. 

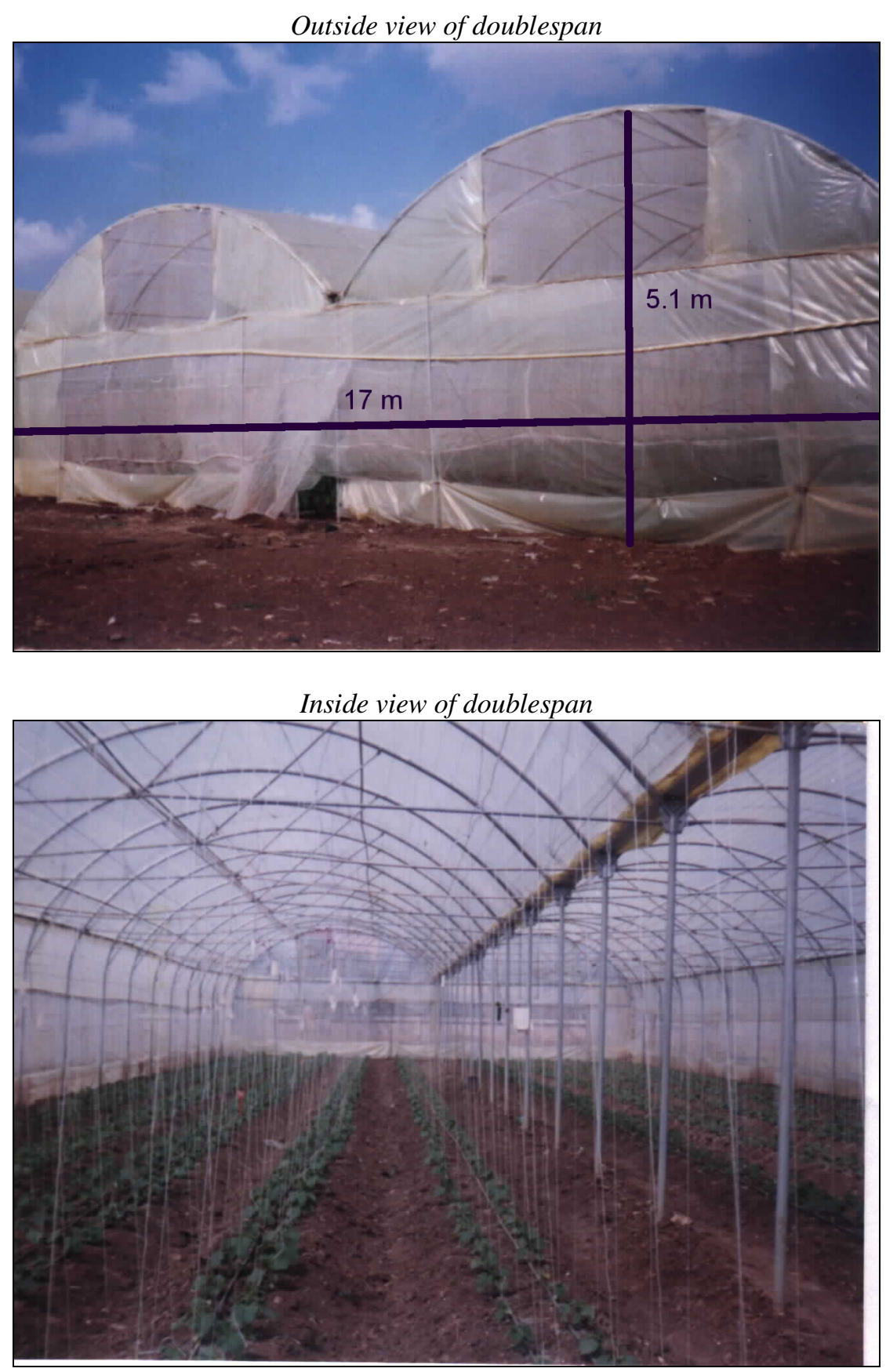

Figure 2. Doublespan plastic house having two round-arches (5.1 $\mathrm{m}$ height, $17 \mathrm{~m}$ width and $55 \mathrm{~m}$ length) covered an area of $935 \mathrm{~m}^{2}$.

\section{Experimental design and statistical analysis}

The experiment included 8 treatments which were the combinations of two growing seasons, two types of plastic houses and two hybrids of cucumber. The previous treatments were arranged in a split-split-plot design with four replications. The main plots were assigned for growing seasons, the subplots for types of plastic houses and the 
sub-sub plots for the two cultivars. The experimental plot (sub-sub plot) consisted of 144 plants with an area of $48 \mathrm{~m}^{2}$.

Data were tested by analysis of variance according to Little and Hills (1975) [30]. Duncan's multiple range test was used for comparison among treatments means [12].

\section{Data recorded}

\section{Flowering}

Accumulative number of opened female flowers per plant was recorded daily on five plants which were randomly chosen from each experimental plot (sub-sub-plot) starting from the first opened female flower until the end of flowering period.

\section{Fruit yield and its components}

Data included early and total fruits yields and earliness. Early fruits yield was determined (as weight and number of fruits per plant and per square meter) of the first 10 pickings. Total fruits yield was determined (as weight and number of fruits per plant and per $\mathrm{m}^{2}$ ) for all pickings. Earliness was expressed as number of days from transplanting to the first picking of fruits [34].

\section{Downy mildew and powdery mildew infection}

Downy mildew and powdery mildew were estimated weekly as infection percentage inside the plastic houses according to the following formula:

$$
\text { Infection } \%=\frac{\text { Number of infected plants }}{\text { Number of total plants }} \times 100
$$

\section{Economic evaluation}

Economic evaluation of cucumber yield, production cost, income (crop value) and net profit (net return) were studied.

\section{Results and discussion}

\section{Early fruits yield}

\section{Effect of season}

Data in Table 1 indicate that the early summer season caused a highly significant increase in early fruits yield (as weight and number of fruits) when compared with the winter season in both 2000/01 and 2001/02 seasons. The increase in weight and number of fruits of early yield during the early summer season might be due to the positive influence of warmer weather (period from Mar. to Jun.) on vegetative growth and flowering which led to increase in early fruits yield (as number and weight). On the contrary, the reduction of early fruits yield during the winter season might be due to the negative effect of colder weather (period from Nov. to 15 Jan.) on decline vegetative growth and flowering which led to decrease in early fruit yield. The suitable soil and air temperatures and light for improvement of early cucumber yield were emphasized by many investigators. [9], [7], [11] and [31]. 
Table 1. Effect of season on flowering and early and total yields of cucumber plant during 2000/01 and 2001/02 seasons.

\begin{tabular}{|c|c|c|c|c|c|c|c|}
\hline \multirow{3}{*}{$\begin{array}{c}\text { Traits } \\
\text { Treatments } \\
\text { Seasons }\end{array}$} & \multirow{3}{*}{$\begin{array}{l}\text { No. of female } \\
\text { flowers/plant }\end{array}$} & \multirow{2}{*}{\multicolumn{2}{|c|}{ Early fruits yield $/ \mathrm{m}^{2}$}} & \multicolumn{4}{|c|}{ Total fruits yield } \\
\hline & & & & \multicolumn{2}{|c|}{ /plant } & \multicolumn{2}{|c|}{$/ \mathrm{m}^{2}$} \\
\hline & & $\begin{array}{l}\text { Wt. of } \\
\text { fruits } \\
(\mathrm{kg})\end{array}$ & $\begin{array}{l}\text { No. of } \\
\text { fruits }\end{array}$ & $\begin{array}{l}\text { Wt. of } \\
\text { fruits } \\
(\mathrm{kg})\end{array}$ & $\begin{array}{l}\text { No. of } \\
\text { fruits }\end{array}$ & $\begin{array}{l}\text { Wt. of } \\
\text { fruits } \\
(\mathrm{kg})\end{array}$ & $\begin{array}{l}\text { No. of } \\
\text { fruits }\end{array}$ \\
\hline \multicolumn{8}{|c|}{$2000 / 01$ seasons } \\
\hline Winter season & $25.8 \mathrm{~b}$ & $1.512 \mathrm{~b}$ & $19.8 \mathrm{~b}$ & $1.670 \mathrm{~b}$ & $21.7 \mathrm{~b}$ & $5.010 \mathrm{~b}$ & $65.1 \mathrm{~b}$ \\
\hline $\begin{array}{l}\text { Early summer } \\
\text { season }\end{array}$ & $46.1 \mathrm{a}$ & $2.994 \mathrm{a}$ & $36.6 \mathrm{a}$ & $3.325 \mathrm{a}$ & $40.5 \mathrm{a}$ & $9.975 \mathrm{a}$ & $121.5 \mathrm{a}$ \\
\hline F test & $* *$ & $* *$ & $* *$ & $* *$ & $* *$ & $* *$ & $* *$ \\
\hline \multicolumn{8}{|c|}{ 2001/02 seasons } \\
\hline Winter season & $22.5 \mathrm{~b}$ & $1.323 \mathrm{~b}$ & $16.8 \mathrm{~b}$ & $1.397 \mathrm{~b}$ & $18.5 \mathrm{~b}$ & $4.191 \mathrm{~b}$ & $55.5 \mathrm{~b}$ \\
\hline $\begin{array}{l}\text { Early summer } \\
\text { season }\end{array}$ & $42.5 \mathrm{a}$ & $2.592 \mathrm{a}$ & $34.5 \mathrm{~b}$ & $2.958 \mathrm{a}$ & $38.1 \mathrm{a}$ & $8.874 \mathrm{a}$ & $114.3 \mathrm{a}$ \\
\hline F test & $* *$ & $* *$ & $* *$ & $* *$ & $* *$ & $* *$ & $* *$ \\
\hline
\end{tabular}

$*, * *$ and NS indicate significant differences at $\mathrm{P}<0.05, \mathrm{P}<0.01$ and not significant, respectively, according to $\mathrm{F}$ test.

Values having the same alphabetical letter within each column are not significantly different at the $5 \%$ level, according to Duncan's test.

\section{Effect of plastic houses type (size)}

Data in Table 2 show that using the double span plastic house caused a significant increase in weight of early fruits yield when compared with the single span in both 2000/01 and 2001/02 seasons. However, number of fruits of early yield was not significantly affected by the type of plastic houses in both 2000/01 and 2001/02. The increase in weight of early fruits yield inside the double span house might be due to that the doubles pan house offering better microclimate (increase in minimum and average air temperatures min. relative humidity and light intensity, and natural ventilation which led to increase in vegetative growth and in turn photosynthesis, subsequently increase average fruit weight.

Table 2. Effect of plastic houses type on flowering and early and total yields of cucumber plant during 2000/01 and 2001/02 seasons.

\begin{tabular}{|c|c|c|c|c|c|c|c|}
\hline \multirow{3}{*}{$\begin{array}{c}\text { Traits } \\
\text { Treatments } \\
\text { Houses type }\end{array}$} & \multirow{3}{*}{$\begin{array}{l}\text { No. of female } \\
\text { flowers/plant }\end{array}$} & \multirow{2}{*}{\multicolumn{2}{|c|}{ Early fruits yield $/ \mathrm{m}^{2}$}} & \multicolumn{4}{|c|}{ Total fruits yield } \\
\hline & & & & \multicolumn{2}{|c|}{ /plant } & \multicolumn{2}{|c|}{$/ \mathrm{m}^{2}$} \\
\hline & & $\begin{array}{l}\text { Wt. of } \\
\text { fruits } \\
(\mathrm{kg})\end{array}$ & $\begin{array}{l}\text { No. of } \\
\text { fruits }\end{array}$ & $\begin{array}{l}\text { Wt. of } \\
\text { fruits } \\
(\mathrm{kg})\end{array}$ & $\begin{array}{l}\text { No. of } \\
\text { fruits }\end{array}$ & $\begin{array}{l}\text { Wt. of } \\
\text { fruits } \\
(\mathrm{kg})\end{array}$ & $\begin{array}{l}\text { No. of } \\
\text { fruits }\end{array}$ \\
\hline \multicolumn{8}{|c|}{ 2000/01 seasons } \\
\hline Single span & 35.5 & $2.088 \mathrm{~b}$ & 28.2 & $2.324 \mathrm{~b}$ & 31.0 & $6.972 \mathrm{~b}$ & 93.0 \\
\hline Double span & 36.4 & $2.418 \mathrm{a}$ & 28.2 & $2.671 \mathrm{a}$ & 31.2 & $8.013 \mathrm{a}$ & 93.6 \\
\hline F test & NS & $* *$ & NS & $* *$ & NS & $* *$ & NS \\
\hline \multicolumn{8}{|c|}{ 2001/02 season } \\
\hline Single span & 31.8 & $1.794 \mathrm{~b}$ & 25.2 & $2.070 \mathrm{~b}$ & 27.8 & $6.210 \mathrm{~b}$ & 83.4 \\
\hline Double span & 33.3 & $2.121 \mathrm{a}$ & 26.1 & $2.285 \mathrm{a}$ & 28.7 & $6.855 \mathrm{a}$ & 86.1 \\
\hline F test & NS & $*$ & NS & $*$ & NS & $*$ & NS \\
\hline
\end{tabular}


Table 3. Effect of hybrid on flowering and early and total yields of cucumber plant during 2000/01 and 2001/02 seasons.

\begin{tabular}{|c|c|c|c|c|c|c|c|}
\hline \multirow{3}{*}{$\begin{array}{c}\text { Traits } \\
\text { Treatments }\end{array}$} & \multirow{3}{*}{$\begin{array}{l}\text { No. of female } \\
\text { flowers/plant }\end{array}$} & \multirow{2}{*}{\multicolumn{2}{|c|}{ Early fruits yield $/ \mathrm{m}^{2}$}} & \multicolumn{4}{|c|}{ Total fruits yield } \\
\hline & & & & \multicolumn{2}{|c|}{ /plant } & \multicolumn{2}{|c|}{$/ \mathrm{m}^{2}$} \\
\hline & & $\begin{array}{l}\text { Wt. of } \\
\text { fruits } \\
(\mathrm{kg})\end{array}$ & $\begin{array}{l}\text { No. of } \\
\text { fruits }\end{array}$ & $\begin{array}{l}\text { Wt. of } \\
\text { fruits } \\
(\mathrm{kg})\end{array}$ & $\begin{array}{l}\text { No. of } \\
\text { fruits }\end{array}$ & $\begin{array}{l}\text { Wt. of } \\
\text { fruits } \\
(\mathrm{kg})\end{array}$ & $\begin{array}{l}\text { No. of } \\
\text { fruits }\end{array}$ \\
\hline \multicolumn{8}{|c|}{ 2000/01 season } \\
\hline Brimo & $32.1 \mathrm{~b}$ & $2.022 \mathrm{~b}$ & $24.6 \mathrm{~b}$ & $2.248 \mathrm{~b}$ & $27.2 \mathrm{~b}$ & $6.744 \mathrm{~b}$ & $81.6 \mathrm{~b}$ \\
\hline Petostar & $39.9 \mathrm{a}$ & $2.484 \mathrm{a}$ & $31.8 \mathrm{a}$ & $2.747 \mathrm{a}$ & $35.0 \mathrm{a}$ & $8.241 \mathrm{a}$ & $105.0 \mathrm{a}$ \\
\hline F test & $* *$ & $* *$ & $* *$ & $* *$ & $* *$ & $* *$ & $* *$ \\
\hline \multicolumn{8}{|c|}{$2001 / 02$ season } \\
\hline Brimo & $30.0 \mathrm{~b}$ & $1.716 \mathrm{~b}$ & $23.1 \mathrm{~b}$ & $1.978 \mathrm{~b}$ & $25.5 \mathrm{~b}$ & $5.934 \mathrm{~b}$ & $76.5 \mathrm{~b}$ \\
\hline Petostar & $35.0 \mathrm{a}$ & $2.199 \mathrm{a}$ & $28.2 \mathrm{a}$ & $2.377 \mathrm{a}$ & $31.1 \mathrm{a}$ & $7.131 \mathrm{a}$ & $93.3 \mathrm{a}$ \\
\hline F test & $* *$ & $* *$ & $* *$ & $* *$ & $*$ & $* *$ & $*$ \\
\hline
\end{tabular}

$*, * *$ and NS indicate significant differences at $\mathrm{P}<0.05, \mathrm{P}<0.01$ and not significant, respectively, according to $\mathrm{F}$ test.

Values having the same alphabetical letter within each column are not significantly different at the 5\% level, according to Duncan's test.

Table 4. Effect of season-plastic houses type-hybrid interaction on flowering and early and total yields of cucumber plant during 2000/01 and 2001/02 seasons.

\begin{tabular}{|c|c|c|c|c|c|c|c|c|c|}
\hline \multirow{2}{*}{\multicolumn{3}{|c|}{$\begin{array}{c}\text { Traits } \\
\text { Treatments }\end{array}$}} & \multirow{3}{*}{$\begin{array}{c}\text { No. of } \\
\text { female } \\
\text { flowers/ } \\
\text { plant }\end{array}$} & \multirow{2}{*}{\multicolumn{2}{|c|}{ Early fruits yield $/ \mathrm{m}^{2}$}} & \multicolumn{4}{|c|}{ Total fruits yield } \\
\hline & & & & & & \multicolumn{2}{|c|}{ /plant } & \multicolumn{2}{|c|}{$/ \mathrm{m}^{2}$} \\
\hline $\begin{array}{c}\text { Season } \\
\mathrm{s}\end{array}$ & $\begin{array}{c}\text { Houses } \\
\text { type }\end{array}$ & Hybrids & & $\begin{array}{c}\text { Wt. of } \\
\text { fruits } \\
(\mathrm{kg})\end{array}$ & $\begin{array}{l}\text { No. of } \\
\text { fruits }\end{array}$ & $\begin{array}{l}\text { Wt. of } \\
\text { fruits } \\
(\mathrm{kg})\end{array}$ & $\begin{array}{l}\text { No. of } \\
\text { fruits }\end{array}$ & $\begin{array}{l}\text { Wt. of } \\
\text { fruits } \\
(\mathrm{kg})\end{array}$ & No. of fruits \\
\hline \multicolumn{10}{|c|}{ 2000/01 seasons } \\
\hline \multirow{4}{*}{$\begin{array}{l}\text { Winter } \\
\text { season }\end{array}$} & Single & Brimo & 21.1 & 1.122 & 16.2 & 1.248 & $17.1 \mathrm{f}$ & 3.744 & $51.3 \mathrm{f}$ \\
\hline & & Petostar & 25.9 & 1.395 & 19.8 & 1.549 & $21.7 \mathrm{e}$ & 4.647 & $65.1 \mathrm{e}$ \\
\hline & Double & Brimo & 24.5 & 1.524 & 19.2 & 1.684 & $21.0 \mathrm{e}$ & 5.052 & $63.0 \mathrm{e}$ \\
\hline & & Petostar & 31.7 & 2.004 & 24.6 & 2.198 & $27.2 \mathrm{~d}$ & 6.594 & $81.6 \mathrm{~d}$ \\
\hline \multirow{4}{*}{$\begin{array}{c}\text { Early } \\
\text { summe } \\
\text { r } \\
\text { season }\end{array}$} & Single & Brimo & 44.2 & 2.700 & 35.4 & 3.007 & $39.4 \mathrm{~b}$ & 9.021 & $118.2 \mathrm{~b}$ \\
\hline & & Petostar & 50.9 & 3.135 & 41.4 & 3.492 & $45.9 \mathrm{a}$ & 10.476 & $137.7 \mathrm{a}$ \\
\hline & Double & Brimo & 38.4 & 2.745 & 28.5 & 3.053 & $31.3 \mathrm{c}$ & 9.159 & $93.9 \mathrm{c}$ \\
\hline & & Petostar & 51.0 & 3.396 & 41.1 & 3.749 & $45.4 \mathrm{a}$ & 11.247 & $136.2 \mathrm{a}$ \\
\hline \multicolumn{3}{|c|}{ F test } & NS & $\mathrm{NS}$ & NS & NS & $*$ & NS & $*$ \\
\hline \multicolumn{10}{|c|}{ 2001/02 seasons } \\
\hline \multirow{4}{*}{$\begin{array}{l}\text { Winter } \\
\text { season }\end{array}$} & Single & Brimo & 20.1 & 1.062 & 15.0 & 1.161 & 16.6 & 3.483 & 49.8 \\
\hline & & Petostar & 23.6 & 1.281 & 18.3 & 1.419 & 20.1 & 4.257 & 60.3 \\
\hline & Double & Brimo & 21.5 & 1.170 & 14.7 & 1.293 & 16.1 & 3.879 & 48.3 \\
\hline & & Petostar & 25.0 & 1.776 & 19.2 & 1.716 & 21.1 & 5.148 & 63.3 \\
\hline \multirow{4}{*}{$\begin{array}{l}\text { Early } \\
\text { summe } \\
r \\
\text { season }\end{array}$} & Single & Brimo & 39.3 & 2.160 & 31.5 & 2.722 & 35.0 & 8.166 & 105.0 \\
\hline & & Petostar & 44.1 & 2.676 & 36.3 & 2.979 & 39.7 & 8.937 & 119.1 \\
\hline & Double & Brimo & 39.1 & 2.475 & 31.2 & 2.737 & 34.3 & 8.211 & 102.9 \\
\hline & & Petostar & 47.5 & 3.057 & 39.0 & 3.395 & 43.4 & 10.185 & 130.2 \\
\hline \multicolumn{3}{|c|}{ F test } & NS & $\mathrm{NS}$ & NS & NS & NS & NS & NS \\
\hline
\end{tabular}

$*, * *$ and NS indicate significant differences at $\mathrm{P}<0.05, \mathrm{P}<0.01$ and not significant, respectively, according to $\mathrm{F}$ test.

Values having the same alphabetical letter within each column are not significantly different at the 5\% level, according to Duncan's test 


\section{Effect of hybrid}

Data in Table 3 illustrate that the differences were highly significant in both 2000/01 and 2001/02. Petostar hybrid had higher number and weight of early fruits yield than those of Primo hybrid. The superiority of Petostar hybrid in early fruits yield (as number and weight) might be due to increase in vegetative growth and number of female flowers.

\section{Effect of season - plastic houses type - hybrid interaction}

Data in Table 4 show that the interaction among season, plastic houses type and hybrid had no significant effect on early fruits yield (as weight and number of fruits).

\section{Total fruits yield}

\section{Effect of season}

Data in Table 1 illustrate that the early summer season caused a highly significant increase in total fruits yield (as weight and number of fruits) when compared with the winter season in 2000/01 and 2001/02. Similar results were observed inside unheated plastic houses [16], [17] and [5].

The increment of total fruits yield during the early summer season more than during the winter season might be due to that the microclimate and soil temperature were better in the early summer season than in the winter one which led to more vigorous growth and increase in number of female flowers. The effect of air and soil temperatures and light were demonstrated by some researchers [27], [11], [32], [28] and [23].

\section{Effect of plastic houses type (size)}

Data in Table 2 demonstrate that application of the double span house had a significant increase in weight of total fruits yield when compared with the single span house. However, number of total fruits yield was not significantly affected by type of unheated plastic houses. The increase in weight of total fruits yield inside the double span house might be due to offering better microclimate (increase in minimum and average air temperatures and light intensity than the single span house). In the same line, Hara et al. (1987) [25] mentioned that large and small greenhouses had higher fruit yield than that in large and small tunnels.

\section{Effect of hybrid}

Data in Table 3 illustrate that the differences were highly significant in both 2000/01 and 2001/02. Petostar hybrid had higher total fruits yield (as weight and number of fruits) than those of Primo hybrid. The superiority of Petostar hybrid in total fruits yield (as number and weight) might be due to increase in vegetative growth and number of female flowers. In this concern, El-Aidy and Moustafa (1977) [19] found that there is a high positive correlation (at the age of ten weeks) between stem length of seven cucumber C.V.S. and total yield. 


\section{Effect of season - plastic houses type - hybrid interaction}

Data presented in Table 4 show that the interaction among season, plastic houses type and hybrid had a significant effect on number of total fruits yield in 2000/01 only. Such effect was not significant on weight of total fruits yield in both 2000/01 and 2001/02 seasons. The highest number of total fruits yield was produced from the cucumber plants cv. Petostar hybrid, which was grown inside the double span house during the early summer season.

\section{Effect of plastic house type and season on infection with fungal diseases}

\section{Downy mildew infection}

Data in Table 5 show that downy mildew infection (\%) on cucumber plants was lower inside the unheated plastic house of the double span than inside the single span house at both sampling dates (60 days after transplanting) during the winter and the early summer seasons of 2000/01 and 2001/02. This result might be due to that the natural ventilation inside the double span house was better than that inside the single span.

On the other hand, downy mildew infection was lower during the winter season than during the early summer season. The favourable weather conditions for downy mildew in fields and greenhouse of cucumber were rainy weather after mid summer [33] or high relative humidity [22], [24] and warm nights [22]. Moreover, daily ventilation in plastic greenhouse by $3 \mathrm{hr}$. in the morning and at night, from the end of April to the first 10 days of May, reduced the dew duration on cucumber leaves. The use of natural ventilation for the whole night within the second 10 days and the last 10 days of May reduced downy mildew by 86 and $46 \%$, respectively. Bilgrami and Dube (1976) [4] reported that a relative humidity of $90-100 \%$ and the temperature range of $20-25$ is most conductive. Furthermore, Dixon (1981) [10] noted that the optimal temperature required is $15^{\circ} \mathrm{C}$ with $6 \mathrm{~h}$ moisture on the leaf.

\section{Powdery mildew infection}

Data in Table 5 indicate that powdery mildew infection (\%) on cucumber plants was higher inside the single span house than inside the double span house during the winter and the early summer seasons of 2000/01 and 2001/02. In addition, powdery mildew infection was lower during the winter season than during the early summer season. In this concern, Bilgrami and Dube (1976) [4] reviewed that higher incidence of powdery mildew was during May-June than in winter months as this is due to the effect of temperature rather than relative humidity. Moreover, the same authors noted that powdery mildew is more prevalent in dry area (moisture stress is most important) and dry months of the year, because of the high water content of the conidia which enables them to withstand high moisture stress. Furthermore, Dixon (1981) [10] reported that the pathogen is favoured by dry atmospheric and soil conditions, moderate temperatures, reduced light intensity, fertile soil and succulent plant growth. Optimal conidial germination is at $28^{\circ} \mathrm{C}$ with a range of $22-31$; conidia can germinate in the absence of free water and in RHs as low as 23 percent. 


\section{Economic evaluation}

Data of economic evaluation in terms of total cost $/ \mathrm{m}^{2}$, crop value and net return as a result of the combined interaction of growing seasons, types of plastic houses and hybrids are shown in Table 6 in both 2000/01 and 2001/02 seasons. The results illustrate that there were slight differences in the total $\cos t / \mathrm{m}^{2}$ of interaction treatments which ranged from 3.46 to 3.66 L.E.

As regards to crop value, the highest record was obtained from Petostar $F_{1}$ hybrid grown inside the double span house during the early summer season, followed by Petostar hybrid grown inside the single span house during the same season when compared with the treatment of Primo hybrid grown inside the single span house during the winter season which had the lowest crop value. With respect to net return (net income) $/ \mathrm{m}^{2}$, the highest value was obtained from Petostar hybrid grown inside the double span house during the early summer season compared with the other interactions, especially Primo hybrid grown inside the single span house during the winter season which had the lowest net return. Likewise, the highest net return during all year round (as two cropping seasons per year, i.e., total net return of the winter and the early summer seasons was obtained from Petostar hybrid grown inside the double span house, followed by Petostar hybrid grown inside the single span house.

Table 5. Effect of season-plastic houses type interaction on downy mildew and powdery mildew infection and life period of cucumber plants during the 2000/01 and 2001/02 seasons.

\begin{tabular}{|c|c|c|c|c|c|c|c|c|c|c|c|}
\hline \multirow{2}{*}{\multicolumn{2}{|c|}{$\begin{array}{c}\text { Traits } \\
\text { Treatments } \\
\end{array}$}} & \multicolumn{6}{|c|}{ Infection with fungal diseases $(\%)$} & \multirow{2}{*}{\multicolumn{4}{|c|}{$\begin{array}{c}\text { Period of cucumber plant life } \\
\text { No. of days from }\end{array}$}} \\
\hline & & \multicolumn{3}{|c|}{ Downy mildew } & \multicolumn{3}{|c|}{ Powdery mildew } & & & & \\
\hline Seasons & $\begin{array}{c}\text { Houses } \\
\text { type }\end{array}$ & 30 & 60 & Mean & 30 & $\begin{array}{c}60 \\
\text { days* }\end{array}$ & Mean & \begin{tabular}{|c|} 
Seeds \\
sowing till \\
transplan- \\
ting \\
\end{tabular} & \begin{tabular}{|c|} 
Transplan- \\
ting till \\
$1^{\text {st }}$ picking \\
(earliness)
\end{tabular} & $\begin{array}{c}1^{\text {st }} \text { picking } \\
\text { till end of } \\
\text { harvest }\end{array}$ & $\begin{array}{c}\text { Seeds } \\
\text { sowing until } \\
\text { end of } \\
\text { harvest } \\
\end{array}$ \\
\hline \multicolumn{12}{|c|}{ 2000/01 seasons } \\
\hline Winter & Single & 0.9 & 9.7 & 5.30 & 3.1 & 4.5 & 3.80 & 13 & 31 & 67 & 111 \\
\hline Season & Double & 0.4 & 6.2 & 3.30 & 0.0 & 0.5 & 0.25 & 13 & 31 & 67 & 111 \\
\hline Mean & & 0.65 & 7.95 & 4.30 & 1.55 & 2.5 & 2.03 & & & & \\
\hline Early & Single & 0.3 & 22.0 & 11.20 & 2.2 & 20.8 & 11.50 & 23 & 44 & 82 & 149 \\
\hline $\begin{array}{c}\text { summer } \\
\text { Season }\end{array}$ & Double & 0.0 & 4.0 & 2.00 & 0.3 & 18.2 & 9.25 & 23 & 44 & 82 & 149 \\
\hline Mean & & 0.15 & 13.0 & 6.60 & 1.25 & 19.50 & 10.38 & & & & \\
\hline \multicolumn{12}{|c|}{ 2001/02 seasons } \\
\hline Winter & Single & 1.2 & 10.2 & 5.7 & 0.0 & 23.3 & 11.65 & 13 & 31 & 67 & 111 \\
\hline season & Double & 0.4 & 6.1 & 3.25 & 0.0 & 20.4 & 10.20 & 13 & 31 & 67 & 111 \\
\hline Mean & & 0.80 & 8.15 & 4.48 & 0.0 & 21.85 & 10.93 & & & & \\
\hline Early & Single & 2.2 & 21.5 & 11.85 & 0.0 & 46.2 & 23.10 & 23 & 44 & 82 & 149 \\
\hline $\begin{array}{c}\text { summer } \\
\text { season }\end{array}$ & Double & 0.8 & 3.4 & 2.10 & 0.0 & 23.6 & 11.80 & 23 & 44 & 82 & 149 \\
\hline Mean & & 1.50 & 12.45 & 6.98 & 0.0 & 34.90 & 17.45 & & & & \\
\hline
\end{tabular}

*Number of days from transplanting

Optimal conidial germination is at $28^{\circ} \mathrm{C}$ with a range of $22-31$; conidia can germinate in the absence of free water and in RHs as low as 23 percent. 
Table 6. Economic evaluation of different growing season and types of plastic houses for the two studied hybrids (L.E. $\left./ \mathrm{m}^{2}\right)$ in 2000/01 and 2001/02 seasons.

\begin{tabular}{|c|c|c|c|c|c|c|c|}
\hline \multicolumn{3}{|c|}{ Treatments } & \multirow{2}{*}{$\begin{array}{c}\text { Total } \\
\text { cost } \\
\text { L.E / } \\
\mathrm{m}^{2}\end{array}$} & \multicolumn{2}{|c|}{ 2000/01 seasons } & \multicolumn{2}{|c|}{ 2001/02 seasons } \\
\hline $\begin{array}{l}\text { Growin } \\
\mathrm{g} \\
\text { seasons }\end{array}$ & $\begin{array}{l}\text { Types of } \\
\text { plastic } \\
\text { houses }\end{array}$ & $\begin{array}{c}\text { Hybrid } \\
\text { s }\end{array}$ & & $\begin{array}{c}\text { Crop } \\
\text { value } \\
\text { L.E./ m2 }\end{array}$ & $\begin{array}{l}\text { Net return } \\
\text { L.E. } / \mathrm{m}^{2}\end{array}$ & $\begin{array}{c}\text { Crop } \\
\text { value } \\
\text { L.E./ } \mathrm{m}^{2}\end{array}$ & $\begin{array}{l}\text { Net return } \\
\text { L.E./ } \mathrm{m}^{2}\end{array}$ \\
\hline \multirow{2}{*}{$\begin{array}{l}\text { Winter } \\
\text { season }\end{array}$} & $\begin{array}{l}\text { Single span } \\
\left(467.5 \mathrm{~m}^{2}\right)\end{array}$ & $\begin{array}{c}\text { Primo } \\
\text { Petosta } \\
\text { r }\end{array}$ & $\begin{array}{l}3.50 \\
3.50\end{array}$ & $\begin{array}{l}4.68 \\
5.81\end{array}$ & $\begin{array}{l}1.18 \\
2.31\end{array}$ & $\begin{array}{l}4.35 \\
5.32\end{array}$ & $\begin{array}{l}0.85 \\
1.82\end{array}$ \\
\hline & $\begin{array}{l}\text { Double span } \\
\left(935 \mathrm{~m}^{2}\right)\end{array}$ & $\begin{array}{c}\text { Primo } \\
\text { Petosta } \\
\mathrm{r} \\
\end{array}$ & $\begin{array}{l}3.66 \\
3.66\end{array}$ & $\begin{array}{l}6.32 \\
8.24\end{array}$ & $\begin{array}{l}2.66 \\
4.58\end{array}$ & $\begin{array}{l}4.85 \\
6.44\end{array}$ & $\begin{array}{l}1.19 \\
2.78\end{array}$ \\
\hline \multirow{2}{*}{$\begin{array}{c}\text { Early } \\
\text { summer } \\
\text { season }\end{array}$} & Single span & $\begin{array}{c}\text { Primo } \\
\text { Petosta } \\
\text { r }\end{array}$ & $\begin{array}{l}3.46 \\
3.46\end{array}$ & $\begin{array}{c}9.02 \\
10.48\end{array}$ & $\begin{array}{l}5.56 \\
7.02\end{array}$ & $\begin{array}{l}8.17 \\
8.94\end{array}$ & $\begin{array}{l}4.71 \\
5.48\end{array}$ \\
\hline & Double span & $\begin{array}{c}\text { Primo } \\
\text { Petosta } \\
\text { r }\end{array}$ & $\begin{array}{l}3.64 \\
3.64\end{array}$ & $\begin{array}{c}9.16 \\
11.25\end{array}$ & $\begin{array}{l}5.52 \\
7.61\end{array}$ & $\begin{array}{c}8.21 \\
10.19\end{array}$ & $\begin{array}{l}4.57 \\
6.55\end{array}$ \\
\hline
\end{tabular}

Average price of one kg cucumber during the winter and early summer seasons was 1.25 and 1.0 L.E.

$* 1 \mathrm{US} \$=5.7$ L.E.

\section{REFERENCES}

[1] Abou-Khaled, A., F. El-Aidy (1986): Introduction of plastic tunnels on small farms of the Ismailia Governorate: Preliminary results. - The $1^{\text {st }}$ Symp. on Hort. Sci. Kafr El-Sheikh, Faculty of Agric. Tanta Univ. 16-18, Sept.

[2] Bakker, J.C. (1990): Effects of day and night humidity on yield and fruit quality of glasshouse tomatoes (Lycopersicon esculentum Mill). - J. Hort. Sci. 65: 323-331.

[3] Beytes, C. (1996): What growers want in a greenhouse. - Floriculture International. 6(10): 12-13.

[4] Bilgrami, K.S., H.C. Dube (1976): A Textbook of Modern Plant Pathology - Vikas Publishing House PVT, Ltd, New Delhi, pp. 203-221.

[5] Campioti, C.A.; P. Rocchi; M.F. Salice, R. Taggi (1990): Yield of cucumber and zucchini cvs under non-heated greenhouses with different covers. - Acta Hort. 287: 443-450.

[6] Castilla, N., J. Lopez-Galvez (1994): Vegetable crop responses in improved low-cost plastic greenhouses. - J. Hort. Sci. 69(5): 915-921.

[7] Challa, H., J. Van-de Vooren (1980): A strategy for climate control in greenhouses in early winter production. - Acta. Hort. 106: 159-165.

[8] Chen, D.S; H.S. Zheng, H.Z. Liu (1989): A primary discussion on adjustment of dew duration by natural ventilation to control downy mildew of cucumber in plastic greenhouse. - Hort. Abst. 61: 1951.

[9] Chernyaev, V.P., V.I. Khrapunov (1978): The effect of additional heating on the photosynthesis of cucumbers grown in plastic greenhouses in spring. - Puti Povysh. Urozhainosti Plodov. 1 Ovoshch. Kultur. 78-83. Odessa, Ukrainian, SSR. [Hort. Abst. 49: 421.]

[10] Dixon, G.R. (1981): Vegetable Crop Disease. - Macmillan Publishers Ltd., The Scientific and Medical Division, London, $1^{\text {st }}$ ed. pp. 312-313..

[11] Drews, M.; A. Heissner, P. Augustin (1980): Yield of an early crop of cucumber in relation to temperature and incident radiation intensity. Arciv-fur-Gartenbau. 28: 17-30 [Hort. Abst. 51: 1207].

[12] Duncan, B.D. (1955): Multiple range and multiple F. tests. - Biometrics 11: 1-42. 
[13] El-Abd, M.T.G.; S. Shanan; A.F. Abou-Hadid, M.M. Saleh (1994): Effect of different shading densities on growth and yield of tomato and cucumber plants. - Egypt. J. Hort. 21: $65-80$.

[14] El-Aidy, F. (1979): Preliminary note on using plastic tunnels for vegetable production in Egypt. - Egypt. J. Hort. 6(1): 43-54.

[15] El-Aidy, F. (1986): Tomato production under simple protective tunnels in Egypt. - Acta Hort. 190: 511-514.

[16] El-Aidy, F. (1989): The effect of plastic tunnel orientation on yield of some cucumber varieties in Egypt. - Acta Agronomica Hungarica, 38(3-4): 349-352.

[17] El-Aidy, F. (1990): The effect of planting date, density, variety and shade on production of cucumber under tunnels. - Acta Hort. 287: 281-287.

[18] El-Aidy, F. (1996): Recent developments in Egyptian plasticulture. - Plasticulture 110: 29-34.

[19] El-Aidy, F., S. Moustafa (1977): Cultivation of some cucumber varieties under plastic tunnels during winter. - J. Agric. Res. Tanta Univ., 3(2): 157-161.

[20] Fanourakis, N.E. (1990): Screening procedures for powdery mildew resistance in the cucumber. - Acta Hort. 287: 147-154.

[21] Farag, A.A.A. (2001): Effect of natural ventilation on productivity and fruit quality of cucumber fruit grown under plastic house. - M.Sc. Thesis, Fac. of Agric. Ain Shams Univ. Egypt.

[22] Forsberg, A.S. (1986): Downy mildew-Pseudoperonospora cubensis in Swedish cucumber fields in 1985. - Vaxtskyddsonotiser 50(1): 17-19 [Rev. Plant Pathol. 66: 759, 1987].

[23] Foti, S.; G. Mauromicale, S. Consentino (1990): Effect of supplementary lighting on the biological and agronomic behavior of snap bean, cucumber and summer squash in cold greenhouse. - Acta Hort. 287: 51-58.

[24] Gupta, S.K., K.R. Shyam (1996): Antisporulant activity of some fungicides against Pseudoperonospora cubensis on cucumber. - Indian J. of Mycology and Plant Pathology. 26(3): 293-295.

[25] Hara, H.; M. Izaki, T. Matsuda (1987): The effect of the volume of plastic film covering on growth and yield of melon (Cucumis melo L.) cv. Prince. - Scientific Rep. Fac. Agric. Ibaraki Univ., No. 35: 13-26.

[26] Holder, R., K.E. Cockshull (1990): Effects of humidity on the growth and yield of glasshouse tomatoes. - J. Hort. Sci. 65: 31-39.

[27] Itagi, T. (1976): Studies on the heating systems and control of air and soils temperatures for cucumber and tomato culture in plastic greenhouses. - Kanagawa, Japan, Kanagwa Hort. Exp. Station. [Hort. Abst. 48: 2414, 1978].

[28] Janse, J. (1984): Influence of light on the quality of tomato and cucumber fruits. Groenten-en-Fruit. 40(18): 28-31 [Hort. Abst. 55: 6179, 1985].

[29] Leber, B.; M. Heck (1991): Cultivars of greenhouse cucumbers for integrated cultivation. - Gemuse Munchen 27(3): 144-147 [Hort. Abst. 62: 1120].

[30] Little, T.M., F.J. Hills (1975): Statistical Methods in Agriculture Research. - California Univ., Davis

[31] Papadopoulos, A.P.; Hao-Xiuming, X.M. Hao (2000): Effects of day and night air temperature on growth, productivity and energy use of long English cucumber. - Can. J. Plant Sci. 80(1): 143-150.

[32] Pasternak, D.; E. Rappaport; M. Twersky; I. Borovic, Y. de Malach (1982): Utilization of geothermal brackish water for the production of out of season crops in the Negev desert. - Alternative strategies for desert development and management. Vol. 1. Energy and Minerals (edited by United Nations Institute for Training and Research), 52-60 USA. [Hort. Abst. 53: 8304-1983].

[33] Pettersson, M.L. (1986): Plant protection year 1985-horticulture. - Vaxtskyddsnotiser. 50(1): 13-16. [Rev. Appl. Entomol. Series.-A 75-259, 1987]. 
[34] Van de Vooren, J.; P.J.A.L. de Lint, H. Challa (1978): Influence of varying night temperatures on a cucumber crop. In Potential productivity in protected cultivation. - Acta Hort. 87: 249-255.

[35] Welles, G.W.H.; K. Abak, S. Buyukalaca (1999): Fruit quality of glasshouse cucumber (Cucumis sativus L.) as influenced by cultural factors. - Acta Hort. 492: 113-119. 